DOI https://doi.org/10.32782/2305-9389/2020.23.27

УДК 351.88:342.95

Предко Михайло,

аспірант кафедри публічного управління та публічної служби Національної академії державного управління при Президентові України

\title{
СМИСЛОВІ КОНТЕКСТИ ФЕНОМЕНА «КОРУПЦІЯ»
}

Обтрунтовано актуальність дослідження феномена «корупиія», звернено увагу на поліваріативний характер його осмислення. Підкреслено, щуо корупція, - ие процес «підкуп-продажність», кінцевим результатом якого $\epsilon$ задоволення суто своїх прагматичних інтересів, використання публічних можливостей у приватних інтересах. Зазначено, щз смислові нюанси феномена «корупція» конкретизуються в контексті термінологічного ряду «корупиійність (здатність до реалізаиії певних життєвих установок, щуо мають здатність закріплюватися як стиль поведінки, спосіб життя), політична корупція (використання посадовою особою, громадським чи політичним діячем прав, пов'язаних із його посадою, з метою особистого збагачення), антикорупційна політика (модель, певний алгоритм державних заходів із метою унебезпечення корисливих дій чиновників)». Акиентовано на етимологічному походженні феномена «корупція» та його сочіально-історичних контекстах, які вирізняються різними смисловими домінантами та засвідчують варіативність корупиійних практик. Аналіз уявлень про корупцію в контексті різних парадигм засвідчив, щзо в процесі розвитку певної традииї відбувалися зміни в їі інтерпретації. Зазначено, щу смислові «зрізи» корупиії корелюються залежно від професійних уподобань дослідника - правовий, соиіологічний, економічний, державно-управлінський аспекти. Корупиія, виникаючи та поширюючись у різних суспільних сферах, деформує нормативно визначені форми, методи та механізми державно-управлінської діяльності. Фрагментуючи державну політику, корупщійні схеми дезінтегрують суспільство, сприяють соціальній напруженості, обезсмислюють та нівелюють демократичні норми та иінності. На ичій підставі констатовано, щзо корупційні прояви деморалізують суспільство, мінімізують ефективність антикорупиійних стратегій, послаблюють та знецінюють політико-управлінський цикл прийняття рішень. Причому корупційні практики найбільше підривають довіру та роз 'їдають законні очікування людей.

Ключові слова: корупція, хабар, політична корупція, антикорупційна політика.

\section{Predko Mykhailo. Semantic nuances of the phenomenon "corruption"}

The relevance of the study of the phenomenon of "corruption" is shown, attention is paid to the multivariate nature of its understanding. It is emphasized that corruption is a process of "bribery and venality", the end result of which is the satisfaction of purely pragmatic interests, the use of public opportunities in private interests. It is noted that the semantic nuances of the phenomenon of "corruption" are specified in the context of the terminological series corruption as the ability to realize certain life attitudes that have the ability to consolidate as a style of behavior, lifestyle; political corruption (use of rights by an official, public or political figure, related to his position, for the purpose of personal enrichment), anti-corruption policy (a model, a certain algorithm of state measures to prevent the selfish actions of officials). Emphasis is placed on the etymological origin of the phenomenon of "corruption" and its sociohistorical contexts, which have different semantic dominants and testify to the diversity of corrupt practices. The analysis of ideas about corruption in the context of various paradigms showed that in the course of the development of a certain tradition there were changes in its interpretation. It is noted that the semantic "slices" of corruption are correlated depending on the professional preferences of the researcher - legal, sociological, economic, public administration aspects. Corruption, arising and spreading in various social spheres, distorts the normatively defined forms, methods and mechanisms of state administration. By fragmenting state policy, corruption schemes disintegrate society, contribute to social tension, de-humiliate and make democratic norms and values meaningless and level. On this basis, it is stated that manifestations of corruption demoralize society, minimizes the effectiveness of anti-corruption strategies, weakens and devalues the political and administrative decision-making cycle. Moreover, corrupt practices more undermine trust and corrode people's legitimate expectations.

Key words: corruption, bribery, political corruption, anti-corruption policy.

Проблема корупції упродовж останніх десятиліть стала однією з ключових не тільки в теоретичних пошуках, але і в державній практиці у світі і особливо в Україні. У кожен історичний період відомі вчені, державні діячі і публіцисти знову і знову зверталися до проблеми корупції: написана величезна кількість фундаментальних книг і статей, проведено сотні змістовних міжнародних і національних конференцій, парламентських слухань та круглих столів, розроблені міжнародні та регіональні конвенції, керівні принципи, типові договори, рекомендації про заходи запобігання корупції та боротьби 3 нею. У цьому випадку нас цікавитиме змістовне наповнення феномена «корупція», його поліваріативний характер, який уможливлює «вибудову» певної термінологічної системи, яка функціонально корелюється з різними дослідницькими стратегіями. 
Смисловий діапазон дослідження проблем корупції доволі різноплановий. Умовно виокремимо кілька напрямів дослідження. До першого блоку джерел належать офіційні і робочі документи, закони та нормативно-правові акти України, Європейського Союзу, Європейської комісії, міжнародних організацій, які регламентують діяльність чинних законодавчих і виконавчих органів СС у сфері протидії та боротьби з корупцією. У них сформульовані концептуальні засади та пріоритети у вирішенні цієї проблеми ЄС загалом, у тому числі в Україні. Другий блок джерел представлений працями вітчизняних авторів, в яких розглядаються сутність корупції, особливості громадянського суспільства, його роль у протидії корупції в Україні, світовий досвід запобігання та протидії корупції, етичні засади державних службовців (М. Аніщенко, О. Береза, І. Берназюк, А. Білецький, О. Бусол, Т. Василевська, В. Гошовська, О. Дяченко, М. Мельник, А. Новак, В. Нонік, О. Пухкал, В. Севрук, С. Телешун, А. Тіньков, І. Рейтерович, С. Хаджирадєва, В. Щербань та ін.). Серед зарубіжних авторів (третій блок джерел), які розглядали проблеми корупції та протидії цьому явищу з боку інститутів громадянського суспільства, варто зазначити А. Грейкара (класифікація та аналіз корупції), Ф. Бастіда, Б. Бенітоа, М-Д. Гілламонба, А.-М. Ріос та ін. (чинники запобігання політичної корупції), Д.М. Грека, Д. Маріані, Д. Локателлі, Т. Сайнаті (корупція в державних проєктах та мегапроєктах), Р. Баккера, М. Вачудова, М. Зіловіча, С. Джолі, Е. Едвардса Дж. Кедама, Ф. Костелка, Г. Маркса, Дж. Полка, Я. Рівного, М. Стенбергена, Л. Хуге, Г. Шумахера (сутність антиелітаризму та протидія політичній корупції), М. Горсіра, В. Гейсмана, А. Денкерса та ін. (мотиви корупції серед державних службовців та в царині бізнесу). Водночас у галузі науки державного управління нині недостатня кількість наукових доробок, які стосуються саме осмислення різноманітних аспектів корупції, завдяки якому уможливлюється її комплексне, цілісне дослідження.

Етимологічно термін «корупція» походить від латинського слова corruption - «підкуп», «псування». У римському праві термін «соrrumpere» передбачає участь у діяльності кількох (не менше двох) осіб, метою яких $\epsilon$ «псування», «пошкодження» нормального ходу судового процесу або процесу управління справами суспільства. Тому семантично цей термін означає порушення норми, порядку. Поняття «corruptio» в римській юриспруденції ідентифікувалося і як підкуп (отримання або дачу хабара), і як незаконне використання особою свого публічного статусу, поєднане 3 отриманням вигоди. Тут йдеться про моральнісний аспект вчинку.

У словнику іншомовних слів корупція - це «1) підкуп хабарами, продажність серед державних, громадських діячів, а також урядовців і службовців державного апарату. 2) Становище, коли це явище охоплює урядові і адміністративні кола» [17, с. 301]. Отже, корупція - це не лише процес, який здійснюється в межах «підкуп-продажність», але й певний стан, певна установка свідомості на спосіб життя. В останньому випадку йдеться про корумпованість, яка часто спричиняється закладеними в нормах права можливостями сприяння корупційним діям. Тому одним із засобів запобігання корупції є моніторингова експертиза, яка покликана бути лакмусовим папірцем, індикатором для перевірки на корупціогенність нормотворчості. До речі, ця практика імплементована в українське законодавство на основі міжнародних антикорупційних документів.

У Словнику української мови корупція визначається як «підкупність, продажність урядовців і громадських діячів» [18, с. 302]. Однак важко погодитися з таким визначенням, оскільки феномен корупції - це не лише підкуп; він значно ширший, бо є певним соціальним явищем. Безперечно, поняття корупції не може ототожнюватися лише з посадовим злочином, у тому числі і таким, як хабарництво. В. Даль визначав хабар як «плату або подарунок посадовій особі, щоб уникнути докорів сумління, або ж підкуп його на незаконну справу», а далі наводив синонімічний ряд, який засвідчував, що хабарі в Росії, залежно від ситуації, приховувалися під численними евфемізмами, такими як «побори, дари, гостинці, приношення...» [5]. Якраз для тих, хто хотів би розібратися в різновидах хабарів [14, с. 26-34], а також вивчити можливості та способи їх отримання, в 1830 році в друкарні Н. Греча вийшов сатиричний твір під інтригуючою назвою: «Мистецтво брати хабарі. Рукопис, знайдений у паперах Тяжалкіна, померлого титулярного радника», в якому автор зазначає: «По-перше, людині властива спонука відшукувати собі їжу і задоволення, а так як хабарі живлять і радують, то немає ні найменшого сумніву, що вони властиві людській природі. По-друге, світ управляється спокусою, чому ж ми повинні бути винятком із загального правила?» [14, с. 18-19]. Е. Перцов подає різні види хабарів, сутність яких, незважаючи на їх різноманітний характер, одна - підкуп, своєрідне жертвопринесення, задобрення з метою одержання вигоди. Тому хабарі здійснюються: «По-перше, натурою - до цього розряду зараховуються обіди, подарунки на пам'ять любові і дружби, сюрпризи в дні іменин або народження самого хабарника, його дружини і дітей, ненавмисне забуті речей на столі чи в будинку хабарника <..> Друга категорія хабарів появилася на світ водночас із винаходом грошей, і стягується ходячою монетою за курсом, але з усієї 
державної монети, переважно обирайте асигнації тому, що вони переходять із рук в руки без шуму і без стуку <...> Третій тип хабара використовується особами кращого і знатного походження: це взаємні послуги або за посадою або по приязні» [14, с. 26-32].

Е. Перцов звертає увагу на стримуючі чинники, даючи напутні поради, як уникнути відповідальності і як можна маніпулювати прохачем. «Що звичайно утримує людей в страху? Суд Божий, суд цивільний і суд громадський, тобто втрата доброго імені; ось три головні пружини, якими умиротворяються пристрасті і управляється механізм народної моральності; саме вони зупиняють сміливця готового зважитися на все...» [14, с. 12]. Отже, страх перед покаранням убезпечує людину від здійснення того чи іншого протиправного вчинку. Отже, корупція - це соціально-правове явище, що виражається в протиправній дії, вчинку, що порушує норми спільноти, підриває іiі основи, порушує права і свободи особистості.

Власне, історія корупції безпосередньо пов'язана з історією формування держави. А. Наумов зазначає, що перші свідчення про корупцію і боротьбу з нею сягають глибини тисячоліть, зокрема, 2318-2311 pр. до н.е., часу правління Урукагін, царя міста-держави Лагаша в стародавній Месопотамії [12]. Проте у Стародавньому Римі та Афінах боротьба з корупцією велась у площині суспільної моралі та суспільного контролю. Наприклад, Цицерон у судових виступах наводить численні факти зловживання при виборах на посаду претора, а також інших магістратів при виконанні ними своїх обов'язків. Так, у промові «Проти Верреса» він зазначав: «Як міський претор він пограбував храми і громадські будівлі i, разом із тим, як суддя, всупереч загальноприйнятому порядку, присуджував і роздавав майно і володіння» [19, с. 46]. Загалом Цицерон вирізнявся комплексним підходом до проблеми боротьби 3 корупцією. Вважаючи умовою успішності антикорупційної політики моральне вдосконалення громадян, Цицерон сформулював цілий ряд законодавчих заходів, включаючи наявність виборних органів влади з чітко визначеною компетенцією, змінюваність посадових осіб, підтримання атмосфери поваги до органів публічної влади, встановлення тимчасових і вікових обмежень на здійснення магістратур, заборону посадових призначень заради особистої вигоди, заборону магістратам під страхом покарання давати і приймати подарунки. Таким чином, розробляючи стратегічний курс боротьби з корупцією, Цицерон приділяє особливу увагу його моральнісно-правовій складовій частині.

Загалом можна стверджувати про наявність у давньоримському праві цілком оформленої антикорупційної концепції, що включає комплекс каральних, правовідтворюючих, регулятивних і превентивних заходів. Однак сукупність зазначених заходів важко назвати збалансованими, оскільки все-таки домінуючим був репресивний підхід у державній стратегії боротьби з корупцією. При цьому також доводиться констатувати про відсутність дійсної державної волі до безкомпромісної і системної боротьби з корупцією. Як цілком слушно зазначає С. Александровська, «корупція (електоральна і посадова), що досягла до кінця першого століття до н.е. безпрецедентних масштабів, стала однією з найважливіших причин загибелі давньоримської республіки» [1]. Отже, ще в Стародавньому Римі ставилося питання про аморальний характер корупції, що призводило до нівелювання особистості й до знищення ії інституційних форм існування. Важко не погодитися з такою тезою: «Корупція - це найбільш властивий злочинним організаціям стиль відносин, смертельний процес, який знищує совість людей, сприяє незаконності і вбиває тих, хто їі поширює» [9].

Однак високий рівень політизації законодавчої і правозастосовної практики в Стародавньому Римі у сфері боротьби з корупцією нівелював потенціал державних антикорупційних заходів. Проте не можна не визнати конструктивізм давньоримських юристів, які намагалися гармонізувати співвідношення між функціями і цілями юридичної відповідальності за корупцію: реалізація каральної функції супроводжувалася майновою відповідальністю винного, яка зобов'язувала відшкодувати заподіяну шкоду в розмірі, що значно перевищує пряму дійсну шкоду.

Як засвідчують історики, з давніх-давен також на теренах України була неприйнятна корупція - відстежується намагання наших предків протидіяти корупції. Наприклад, у Запорізькій Січі, Велика екстрадинаційна Рада у своєму присуді від 23 грудня 1764 року встановила припис щодо заборони використання військової казни на особисті потреби. А якщо отаман куреня поводиться «несправно», або потакає злодіям, він підлягає покаранню і наступного разу не може бути обраний отаманом [10, с. 12].

Наведені приклади не вичерпують усього арсеналу правових заходів боротьби з корупцією, який використовувався в минулому. Однак навіть наведене дає нам змогу зробити деякі висновки. По-перше, можна стверджувати, що корупція - це певне соціальне явище, яке іманентно породжувало протидію зловживанню владою у вигляді правових норм. По-друге, в наведених історичних прикладах корупційні дії описуються як протиправна поведінка, якій властива корислива спрямованість. По-третє, суб'єктами протиправних зловживань здебільшого є представники одного з ієрархічних ступенів влади. 
У більшості документів ООН і Ради Свропи корупція розглядається як зловживання державною владою для одержання вигоди в особистих цілях, у цілях третіх осіб або груп. Схоже визначення існує в Законі України «Про запобігання корупції», в якому зазначається: «Корупція - використання особою, наданих їй службових повноважень чи пов'язаних із ними можливостей із метою одержання неправомірної вигоди або прийняття такої вигоди чи прийняття обіцянки/пропозиції такої вигоди для себе чи інших осіб або, відповідно, обіцянка/пропозиція чи надання неправомірної вигоди особі, або на іiі вимогу іншим фізичним чи юридичним особам із метою схилити цю особу до протиправного використання наданих їй службових повноважень чи пов'язаних із ними можливостей» [8].

Отже, в правовому підході до осмислення феномена «корупція», з одного боку, звертається увага на використання особою службових повноважень із метою одержання неправомірної вигоди, а з іншого боку - обіцянка чи надання неправомірної вигоди особі або на її вимогу іншим фізичним чи юридичним особам із метою схилити цю особу до протиправного використання наданих їй службових повноважень або пов'язаних із ними можливостей. Таким чином, корупція - це девіантна поведінка, спрямована на отримання особистої вигоди за суспільний рахунок, що відходить від встановлених законом публічних норм виконання своїх професійних обов'язків. Тому корупція має безпосередній політичний «відтінок», бо полем її розгортання виступає інституціональне середовище, в якому задіяні економічні, інформаційні ресурси. «Тут також варто зазначити, що стійкі взаємини між політичними лідерами, державними службовцями та представниками бізнесу, засновані на неринковому розподілі ресурсів у вигляді зловживання публічними повноваженнями, що утворюють корупційну мережу» $[4$, с. 4]. Отже, корупція виходить за рамки дачі та одержання хабарів, тільки лише підкупу посадової особи, а набуває характеру певних установок, алгоритму, що закріплюється в стилі поведінки. Водночас корумповані зв'язки не обов'язково характеризуються стійкістю, тривалістю, вони можуть бути і разовими, ситуативними. Все залежить від внутрішньої установки людини, ії готовності використовувати свої повноваження у власних корисливих інтересах. «Слабкість! Що зазвичай розуміють під словом слабкість? Ту особливу властивість, яка керує людиною в повній мірі, управляє іiі думкою і спонукає до вчинків, на котрі раніше ніяка сила не могла б спонукати іiі. Хто проник у слабкість людини, той вже має в своїх руках іiі саму і все, що належить їй: честь, владу, майно» [14, с. 59]. Отже, щоб цю піддатливість мінімізувати, варто змістовне наповнення корупції розширити контекстуально. Ми переконані, що стратегування в системі державного управління має орієнтуватися не лише на питання боротьби з корупцією на державному рівні, а й на питання міри легітимного втручання громадськості в розроблення антикорупційної політики держави та запровадження належних інструментів такого втручання. Лише в такому разі формуватиметься ефективна система стримувань і противаг, аби жодна інституція, жоден посадовець не могли узурпувати владу.

При цьому потрібно враховувати, що феномен «корупція» деморалізує суспільство, підриває віру в справедливість, піддає руйнації демократичні цінності як основу державності. Безперечно, «державний чиновник або політичний діяч, який, діючи заради власного зиску, порушує чинне законодавство і норми державної установи, завдає шкоди інтересам громадськості й суспільної моралі або догоджає третій стороні (іï форми можуть мати різні ознаки), яка винагороджує державного чи політичного діяча матеріальними благами чи іншими послугами за доступ до фінансово-матеріальних ресурсів і важелів влади» [7, с. 350]. Отже, проблема корупції безпосередньо пов'язана з особистісно-моральними установками державного службовця, з тими соціальними цінностями, на яких грунтується державність.

У соціологічному «зрізі» проблем осмислення корупції та іiї протидії звертається увага на інституційні причини корупції, в основі яких лежать ідеї С. Хантінгтона, П. Бурдьє, Р. Мертона, Р. Міхельса, М. Вебера, С. Роуз-Еккерман, А. Токвіля про корупцію як дисфункцію системи управління, що має амбівалентний характер. 3 одного боку, корупційні дії дають змогу одним соціальним групам зберегти соціально-політичне та економічне становище в суспільстві, а для інших стають способом асиміляції в політичну систему за відсутності інших легітимних засобів. 3 іншого боку, високий рівень корупції автоматично стає загрозою для демократії, основою спекуляцій з приводу іï механізмів і процедур. Тим паче, «що високий рівень корупції має значний негативний вплив на національну конкурентоспроможність» $[20$, p. $7-8]$.

Проведення соціологічного аналізу корупції, виявлення основних етапів іiї соціального генезису дали змогу одному із засновників соціології злочинності Е. Дюркгайму з'ясувати такі методологічні орієнтири в дослідженні корупції: « 1) корупція як злочин - дисфункція соціальної системи; 2) боротьба поліцейськими методами 3 корупцією безглузда; 3) корупція як соціальне явище - частина культури населення〉 [2, с. 9-10]. Натомість М. Вебер зробив висновок про прийнятність корупції за умови, що вона підсилює позицію еліт, які гарантують прискорення змін у суспільстві. Розглядаючи відкуп 
державних податків як один із механізмів нормального функціонування суспільства, він зазначав, що така політика сприяла формуванню раціональної бюрократії і була історично необхідною.

П. Бергер і Т. Лукман [3], розглядаючи соціально конструйовану реальність, що постійно відтворюється людьми під впливом іiї інтерпретації і знань про неї, виокремлюють певні іiі рівні, зокрема хабітуалізацію (перетворення на повсякденність), типізацію (зразки взаємодій, які втілюються в соціальній реальності і становлять соціальну структуру, що своєю чергою є одним із найголовніших елементів реальності повсякденного життя), інституціоналізацію (закріплює типізацію завдяки колективним уявленням та зусиллям), імідж (сприйнятність сконструйованої реальності). Загалом для з'ясування сутності корупції, іiі певних моделей мають значення всі рівні, що пропонують П. Бергер та Т. Лукман. Однак для нашого дослідження значний інтерес становить рівень інституціоналізації, бо «інститути вже завдяки самому факту їх існування контролюють людську поведінку, встановлюючи зумовлені нею зразки, які надають поведінці один із багатьох теоретично можливих напрямів. Важливо підкреслити, що цей контролюючий характер притаманний інституціоналізації як такій, незалежно від і ще до того, як створені будь-які механізми санкцій, що підтримують інститут. Ці механізми (сукупність яких становить те, що зазвичай називають системою соціального контролю), звичайно ж, існують у багатьох інститутах і у всіх агломераціях інститутів, які ми називаємо товариствами» [3, с. 93-94].

Однією із провідних фахівчинь у царині дослідження корупції вважається С. Роуз-Аккерман. Розглядаючи функціонування корупції в різних сферах життя суспільства, авторка обгрунтовує цей феномен надмірним втручанням держави в економічні процеси. С. Роуз-Аккерман - професорка Сльського університету і співдиректорка Центру права, економіки та публічної політики факультету права. Вона подає різноманіття підходів до аналізу корупційних явищ, розглядаючи їх як економічний, політичний і культурний феномен. Свою книгу С. Роуз-Аккерман починає з того, що пропонує таке визначення поняття корупції: «Будь-яка держава контролює розподіл матеріальних привілеїв і пільг і визначає розмір податкового тягаря. Розподілом привілеїв і пільг зазвичай займаються державні чиновники, які мають право діяти на свій розсуд. У приватних осіб і компаній, які прагнуть отримати режим найбільшого сприяння, може виникнути бажання купити такий режим. Плата за отримання матеріальної вигоди і $є$ випадком корупції» [16, с. 7]. 3 її точки зору, корупція для корупціонерів виступає в ролі раціонального способу оптимізації витрат. Крім цього, вона зазначала, що навіть якщо корупційний фактор і показники економічного зростання уживаються мирно, проте це призводить до стимулювання нових витрат і спотворення економічних цілей. Суб'єкт, пов'язаний у корупційних мережах, буде намагатися знайти оптимальний для себе спосіб реалізації особистих інтересів при обмежених ресурсах. Акцентуація на смислові нюанси корупції в економічній царині уможливила введення в цю проблематику терміна «ренто орієнтована поведінка», яка використовується для характеристики поведінки економічних агентів в умовах інституціональних перетворень, коли індивідуальні зусилля із максимізації вартості породжують втрати суспільства, а не вигоду для нього.

Власне, корупція існує в тій чи іншій формі у всіх країнах, де $є$ політико-бюрократичний апарат, тому що вона тісно пов'язана з владою і управлінням. Корупція паралізує управлінську функцію держави, тому вона може бути визнана як серйозний збій у роботі системи управління, бо «корупція передбачає несанкціоновану торгівлю уповноваженими органами влади» [21, р. 89]. Йдеться про політичну корупцію. Найчастіше специфіка політичної корупції бачиться в тому, що вона є центральною частиною зворотного боку публічної політики, що свідчить про недосконалість системи влади. У чому ж сутність, власне, політичної корупції?

Доволі широкий смисловий діапазон визначень політичної корупції подає В. Гошовська [4, с. 5-6], зокрема як поведінку певних осіб, як «певний (спотворений) стан взаємовідносин держави та суспільства», як маніпуляцію політичних інститутів, як одну із функціональних норм авторитарних режимів форм тощо. Врешті-решт дослідниця зазначає, що це поняття грунтується на таких елементах, як нелегітимність, використання можливостей і повноважень, якими наділені носії публічної влади, можливість досягнення певної цілі за рахунок зловживання владою. Саме тому політична корупція це нелегітимне використання владного положення для досягнення політичних (збереження влади, їі отримання, розширення повноважень) або особистих цілей» [4, с. 10]. Отже, саме політична корупція, iї «вплетення» в політико-управлінське середовище засвідчує неефективність влади, iї недієздатність. Зазначимо, що політична корупція має чотири основних смислових нюанси, зокрема, незаконні дії у сфері політики (наприклад, хабарництво); другий нюанс пов'язаний безпосередньо з державною практикою, причому може бути легальним, однак мати неетичний характер. Третій аспект пов'язаний із конфліктом інтересів у посадових осіб. І в останньому аспекті фіксується визначення, що належить до політичних дій, які не відповідають інтересам суспільства [22, р. 11]. Отже, політична корупція 
є складником усіх політичних практик; вона в них немовби «вмонтована», вичурно приховуючись під привабливою обгорткою (щось на кшталт гонорарних політичних практик).

Незважаючи на різні підходи в науковому дискурсі до визначення терміна «політична корупція», можна виокремити iї загальні специфічні риси. Зокрема, політична корупція - це, по-перше, не повсякденний практичний досвід людини, основною її функціональною сферою є царина політики, зокрема державне та регіональне управління. По-друге, поняття політичної корупції тісно пов'язане 3 поняттям «клієнтизм» (одна 3 форм організації суспільства, в якому суспільні зв'язки вибудовуються у формі «клієнт»-«патрон», де спрацьовує правило особистої вірності, лояльності). По-третє, політична корупція характеризується латентністю (прихованістю, неоприявненістю). По-четверте, далеко не завжди політична корупція має чітко виражене матеріальне втілення - або у вигляді конкретно зумовленого грошового еквівалента, або в обсязі певних послуг. По-п’яте, політична корупція - це «елітарна», або «елітно-владна» корупція, яка передбачає, що особи, які обіймають найвищі державні посади (як призначені, так і обрані), використовують довірені їм ресурси влади не в інтересах суспільства, а в особистих, корисливих цілях для свого політичного збагачення, оскільки суб'єкти правопорушень мають високий соціальний статус. Водночас суб'єкти політичної корупції з огляду на їх статус і можливості можуть формувати правове поле, цілеспрямовано «закладаючи» в нього можливості для подальших корупційних дій, створюючи «правові лакуни», «обхідні шляхи» тощо. По-шосте, політична корупція залежить від конкретно-історичного типу суспільства, тих цінностей, на яких воно грунтується.

Безперечно, поняття «політична корупція» безпосередньо пов'язане з концептом «антикорупційна політика». Вітчизняні науковці В. Василевич, Т. Василевська, В. Нестерович, Е. Расюк, А. Савченко, В. Федоренко [6], А. Новак [16] розробили комплекс наукових праць із питань антикорупційної політики держави та запропонували власну методологію дослідження формування основ антикорупційної політики. Науковцями НАДУ при Президентові України І. Рейтеровичом, М. Стадником, С. Телешуном [15] проведено дослідження з питань формування та реалізації державної антикорупційної політики і запобігання корупції на державній службі. Ефективність заходів, спрямованих на протидію корупції, безпосередньо залежить від діагностики корупції як соціального явища на основі дослідження природи, характеристик, зразків і внутрішньої структури корупції, оскільки корупційна діяльність, будучи об'єктивною формою практики, не може існувати у вакуумі. Це соціальна дія, яку варо розглядати у зв'язку з соціальними відносинами між людьми і в певному історичному контексті. У цьому $є$ важливим не тільки досліджувати змістовне наповнення антикорупційної політики в Україні, але і діагностувати, наскільки запропоновані державою механізми протидії корупції досягають кінцевих результатів. Якось в одного китайського мудреця спитали: «Як зробити каламутну воду прозорою?» Він відповів: «Просто припинити ії каламутити». Його відповідь може стати найкращою порадою українським можновладцям щодо того, як зробити так, щоб робота новостворених антикорупційних органів стала ефективною: «Просто самим перестати красти й брати хабарі».

На наш погляд, антикорупційна політика - це сукупність державних заходів, спрямованих на протидію девіантної поведінки посадових осіб органів державної влади та місцевого самоврядування, спрямованого на задоволення особистих матеріальних або інших інтересів із використанням свого становища, мінімізацію iï наслідків і профілактику відхилень дій чиновників від їхніх формальних обов'язків. Антикорупційна політика виступає не просто стратегією і тактикою повсюдного наступу проти цієї важкої форми посадової злочинності, але постає специфічними напрямками послідовної теоретичної розробки та практичної реалізації спеціальних заходів. У найбільш повному вигляді вони розглядаються в роботах В. Лунєєва [11, с. 20-27]. Серед них на пріоритетному першому місці знаходиться розвиток світоглядно-ментальних антикорупційних передумов подолання корупційної терпимості. До тих пір, поки громадська думка не подолає болючої української толерантності до корупційного акта, боротьба з хабарництвом в Україні - безрезультатна. На другому місці за пріоритетною значущості виступає інституційно-організаційна діяльність, цілеспрямовано підпорядкована завданню подолання корупційних деформацій публічно-державної служби. Третє місце займають спеціальні дії з антикорупційного моніторингу нормативно-правової бази, ретельне відстеження і відфільтровування корупціогенних нормативних статей засобами правової експертизи.

Отже, антикорупційна політика - це постійно здійснювана діяльність державних органів, яка здійснюється в тісній співпраці з інститутами громадянського суспільства, зорієнтована на запобігання та боротьбу з корупцією в системі державного управління та з метою виявлення корупційних злочинів, впровадження дієвих механізмів боротьби з корупцією, підвищення суспільної свідомості та впровадження етичних стандартів поведінки державних управлінців. 
Як засвідчує досвід західних країн, що саме системний підхід до боротьби з корупцією потребує належної інституціоналізації цього процесу. Важливими $є$ постійне проведення оцінки стану справ із корупцією, моніторинг реалізації державної антикорупційної політики, формування світогляду несприйняття корупції. Ці заходи вказують на оцінку суспільством довіри до державної служби та іiі ефективність. Оцінка має здійснюватися неурядовими організаціями та громадськими об'єднаннями.

Отже, виходячи з різноваріативних, багаторівневих характеристик феномена «корупція», його зв'язку 3 поняттями «корупційність», «політична корупція» та «антикорупційна політика», пропонується розглядати їх як семантично споріднені, інваріантні за формою поняття, які мають певні смислові відмінності: з одного боку, можна виокремити більш близькі термінологічні ряди «корупція-корупційність» та «політична корупція - антикорупційна політика», а з іншого - розкрити їх змістовне наповнення: в першому випадку домінуючою характеристикою є процес «підкуп-продажність», що закріплюється в певному способі мислення, стилю поведінки, а в другому цариною їх функціональності виступає політико-управлінське середовище, де відстежується використання посадовою особою, громадським чи політичним діячом прав, пов'язаних із його посадою, з метою особистого збагачення. Натомість антикорупційна політика - це система державних заходів щодо запобігання та протидії корупції серед осіб органів державної влади, спрямованих на мінімізацію іï наслідків і профілактику девіантної поведінки чиновників.

\section{Література:}

1. Александровская С.В. Антикоррупционная концепция в праве Древнеримской Республики (V-I вв. до н. э.) : дис. ... канд. юрид. наук : 12.00.01. Краснодар, 2004. 247 с. URL: http://www.dslib.net/teoria-prava/antikorrupcionnajakoncepcija-v-prave-drevnerimskoj-respubliki.html

2. Алексеев С. В.Коррупция в переходном обществе: Социологический анализ : автореф. дис. ...канд. социол. наук : 22.00.04 . Новочеркаск, 2008. 49 с.

3. Бергер П. Социальное конструирование реальности. Трактат по социологии знания. Москва : Медиум, 1995.323 с.

4. Гошовська В. А. Політична корупція як об єкт наукового дослідження. Збірник наукових праць Національної академї державного управління при Президентові України. Держава та регіони. Серія: Державне управління. 2018. № 2 (62). C. 4-11.

5. Даль В. Толковый словарь живого великорусского языка. URL: http://www.runivers.ru/lib/book3178/

6. Державна антикорупційна політика і запобігання та протидія корупції на публічній службі в органах державної влади і органах місцевого самоврядування : монографія / автор. кол.; В.В. Василевич, Т.Е. Василевська, В.Ф. Нестерович, Е.В. Расюк, А.В. Савченко, В.Л. Федоренко (кер.) та ін.; за ред. проф. Ю.В. Ковбасюка і проф. В.Л. Федоренка. Київ : Вид.-во Ліра-К, 2016. 524 с.

7. Енциклопедичний словник з державного управління / уклад. Ю.П. Сурмін, В.Д. Бакуменко, А.М. Михненко та ін.; за ред. Ю.В. Ковбасюка, В.П. Трощинського, Ю.П. Сурміна. Київ : НАДУ, 2010. 820 с.

8. Закон України «Про запобігання корупції». URL: http://zakon.rada.gov.ua/laws/show/1700-18

9. Корумпована людина поширює сморід, - Папа Франциск. URL: https://credo.pr/2017/06/184556

10. Лепісевич П.М. Козацька держава і право : навчальний посібник з історії держави і права України / П.М. Лепісевич, І.Я. Терлюк. Львів : Край, 2005. 136 с.

11. Лунеев В.В. Коррупция в России. Государство и право. 2007. № 11. С. 20-27.

12. Наумов, А. Коррупция: причины возникновения, влияние и методы борьбы. Мировое и национальное хазяйство. 2009. № 1 (8). URL: https://mirec.mgimo.ru/2009-01/korrupciya-prichiny-vozniknoveniya-vliyaniya-i-metody-borby2

13. Новак А. Принципи формування національної антикорупційної політики. Публічне адміністрування: теорія та практика. 2017. Вип. 1. URL: http://nbuv.gov.ua/UJRN/Patp_2017_1_5.

14. Перцов Э.П. Искусство брать взятки. Рукопись, найденная в бумагах Тяжалкина, умершего Титулярного Советника. Санкт-Петербург : В Типографии Н. Греча, 1830. XI. 74 с.

15. Публічна політика та суспільні зміни в Україні в контексті євроінтеграції : монографія / авт. кол. : С.О. Телешун, С.В. Ситник, І.В. Рейтерович, О.Г. Пухкал та ін. ; за заг. ред. С.О. Телешуна, д-ра політ. наук, проф. Київ : НАДУ, 2017. $248 \mathrm{c}$.

16. Роуз-Аккерман Сьюзан. Коррупция и государство: Причины, следствия, реформы / Пер. с англ. О.А. Алякринского. Москва : Логос, 2010. 356 с.

17. Словник іншомовних слів / Уклад.: С.М. Морозов, Л.М. Шкарупа. Київ : Наук. думка, 2000. 680 с.

18. Словник української мови: в 11 тт. / АН УРСР. Інститут мовознавства; за ред. І.К. Білодіда. Т. 4. Київ : Наукова думка, 1970-1980. 840 с.

19. Цицерон М.T. Речи. Речь против Гая Верреса. URL: http://ancientrome.ru/antlitr/t.htm?a=1267350002

20. An Investigation of the Influence of the Worldwide Governance and Competitiveness on Accounting Fraud Cases: A Cross-Country Perspective / Rabeea S., Judit O., Jozsef P., Domician M. Sustainability. 2018. Vol. 10. № 3. P. 1-11. URL: https://ideas.repec.org/a/gam/jsusta/v10y2018i3p588-d133391.html

21. Graycar A. Corruption: Classification and analysis. Policy and Society. 2015. Vol. 34. № 2. P. 87-96.

22. Grossman M. Political Corruption in America: An Encyclopedia of Scandals, Power, and Greed . Grey House Publishing; 2nd Edition. 2008. 738 p. 